\title{
OONTENTS
}

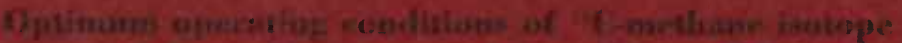

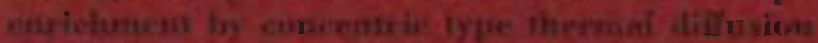

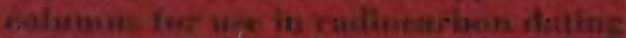

$$
+
$$

H. Butut Srlenkewaer

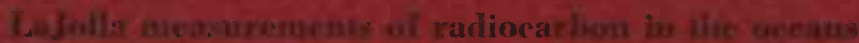

\section{DATE L.1578}

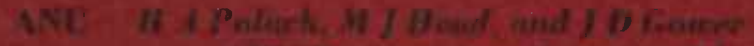

AVC Iteathorartwe Data Live VI

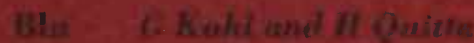

Berlin fationeathons Bates V

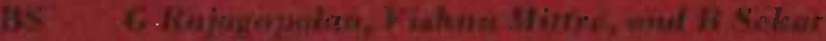

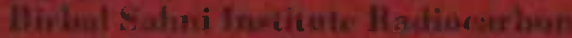

Mhasirenencen if

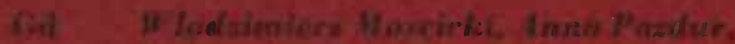

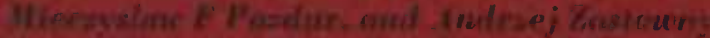

Climice Fodiocarben IJates IV

Li Soren Hakmanam

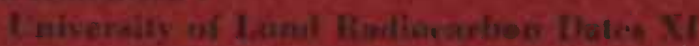

IIIIR 'Themes D Mathera

Marine Ifesuitres Researrir lontitute

Radioearlwon Dates 11

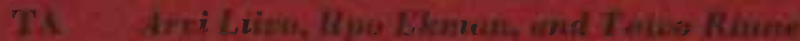

Tarin Radivearform Dates VIf

TA. Bilue

Therin Natiecarbon Datre VHI

TAM! Rot Porker and if II Surket

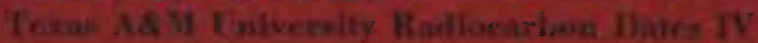

455

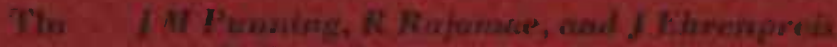

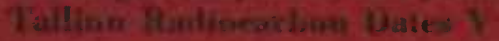

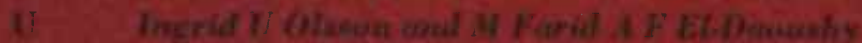

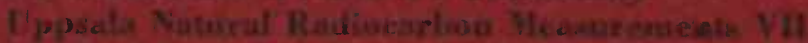

469

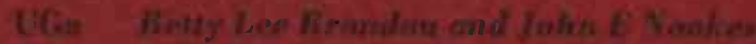

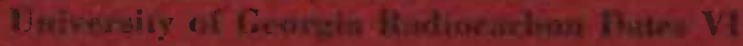

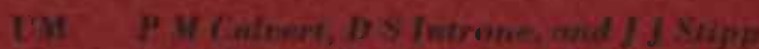

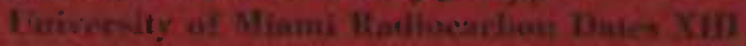

List of Iahuraturibe

Indes: to Voluene 24

524

Erralum 